\title{
Policies Facilitating Firm Adjustment to Globalization
}

\author{
Bernard Hoekman and Beata Smarzynska Javorcik*
}

\begin{abstract}
This paper focuses on policies facilitating firm adjustment to globalization. We briefly review the effects of trade and investment liberalization on firms, focusing on within-industry effects. We postulate that governments' role in supporting the process is to: (i) ensure that firms face "right" incentives to adjust, and (ii) intervene in areas where market failures are present. The main message of the paper is that while many policies could be adopted to address market failures, they need to be carefully designed and implemented in a stable macroeconomic environment. An institutional infrastructure that supports the functioning of modern markets is most important. Pro-active support policies of whatever stripe should be subject to cost-benefit analysis, based on the existence of an identified market failure and monitored for performance and cost effectiveness. Transparency and accountability are critical in ensuring that interventions accomplish their intended objectives rather than being vehicles for rent seeking.
\end{abstract}

JEL codes: F02, F13, O19

Keywords: globalization, adjustment, government policies

World Bank Policy Research Working Paper 3441, November 2004

The Policy Research Working Paper Series disseminates the findings of work in progress to encourage the exchange of ideas about development issues. An objective of the series is to get the findings out quickly, even if the presentations are less than fully polished. The papers carry the names of the authors and should be cited accordingly. The findings, interpretations, and conclusions expressed in this paper are entirely those of the authors. They do not necessarily represent the view of the World Bank, its Executive Directors, or the countries they represent. Policy Research Working Papers are available online at http://econ.worldbank.org.

\footnotetext{
*World Bank and CEPR. 1818 H St, NW Washington, D.C. 20433. Email: bhoekman@,worldbank.org, bsmarzynska@worldbank.org. We are grateful to David Greenaway and two referees for helpful comments on an early draft.
} 


\section{Introduction}

While there exists an extensive literature on firm responses to globalization and ways through which it occurs, including trade, investment, mergers and cross-border alliances, less attention has been paid to government policies facilitating this process. This is the focus of this article. Governments have a twofold role to play in this area. First, they must ensure that firms face "right" incentives to adjust, and second, they should intervene in areas where market failures are present. Governments often fail in the former role. For example, countries may pursue inappropriate macroeconomic policies, such as overvaluation of the exchange rate following trade liberalization, inhibiting export response. Trade polices, including safeguards and antidumping, may attenuate the incentive of firms to adjust, or even create perverse incentives not to adjust (Leidy and Hoekman, 1992; Bown and McCulloch, 2004). The same is true of soft budget constraints and firm or industry subsidies. Regulations hindering firm entry and exit, inflexible labor markets and high minimum wage also contribute to slowing down the adjustment. A key issue in general is the credibility of the overall policy stance, as this will have a major impact on the incentives for firms to incur the costs of adjustment. Credibility can be achieved by avoiding time inconsistency in government actions through appropriate sequencing and the use of external (international) mechanisms, such as trade agreements or international financial institutions, as commitment devices.

Government intervention is in principle warranted in the case of a market failure. For instance, markets may undersupply investment by firms in new activities because of appropriability problems - as soon as an entrepreneur succeeds in identifying a new opportunity for profitable production, entry of imitators prevents recouping of costs. In such a situation, a subsidy or similar incentive can help expand innovation and risk-taking. From an adjustment perspective, this can also induce a reallocation of investment out of declining industries. However, the issue is to address the externality, not to prop up uncompetitive firms or industries (Hausmann and Rodrik 2002). Another example of market failure is knowledge externalities associated with the presence of foreign direct investment (FDI) or exporting activities. If they indeed exist, there may be scope for policies encouraging FDI inflows or facilitating creation of a domestic supplier base. Provision of information on business opportunities abroad could be another area of a potential intervention. 
In practice, intervention in an area may be driven by a combination of ensuring there are incentives to adjust and addressing market failure. Policies toward service sectors are an example. Services are important in terms of facilitating adjustment and creating new opportunities for workers and entrepreneurs. The cost, quality and variety of services other than finance available to firms and consumers are major factors determining the net benefits of trade liberalization and the costs associated with adjustment. However, services are also activities where there is often a need for some type of regulation to address market failures or to achieve social objectives.

The main message of this paper is that many policies could be adopted to facilitate firm adjustment but they need to be carefully designed. They are also second order relative to ensuring a stable macroeconomic environment and an institutional infrastructure that supports the functioning of modern markets in general. Pro-active support policies of whatever stripe should be subject to cost-benefit analysis and be informed by answers to the following types of questions: where is the market failure? What is the objective of a policy? How is performance and cost effectiveness going to be monitored? It should also be recognized that such interventions are frequently associated with the risk of misdiagnosing the problem and the possibility of capture by rent seekers. Thus one must weigh the effectiveness of an imperfectly performing market with an imperfectly performing government and recognize that sometimes the market may work better even in cases of market failure. Should the decision to proceed with a support policy be taken, transparency and accountability are two principles critical in ensuring that a policy does what it is intended to, rather than being a vehicle for rent seeking.

In what follows, we first briefly review the effects of trade and investment liberalization on firms, focusing on adjustment taking place within industries, referring for illustrative purposes to a recent survey of Czech firms (Section 2). We then outline ways in which government policies can encourage this process (Section 3), and end with some concluding remarks (Section 4). "Adjustment" is a big topic, and many aspects will not be addressed. Examples include within-country regional dimensions, the role of income redistribution and social safety nets, and exchange rate and macroeconomic policies. This is not to deny their importance- they are critical for the feasibility, credibility, and sustainability of reforms. We shall refer to them only in passing, however, due to space constraints. 


\section{Effects of trade and investment liberalization on indigenous firms}

We divide our discussion of the effects of globalization on firms into three parts: competition effects, access to new knowledge, and access to new markets.

\section{Competition effects}

Lowering barriers to imports and FDI increases competition as foreign goods and foreign producers enter the domestic market. The magnitude of the effect tends to be much larger in developing countries, which (in part due to previous protection from international competition) lag behind the industrialized nations in terms of technological sophistication, quality and variety of products and productivity. While in the short run the loss of market share to foreign goods or firms may prevent local firms from reaping the benefits of scale and thus lower their productivity, in the medium run weaker firms will be forced to exit, survivors will lower their cost base and/or upgrade their production and as a result the average productivity of indigenous firms will increase.

The existence of the competition effect has been documented by many empirical studies (Roberts and Tybout, 1997). Pavcnik (2002) is a representative example focusing on the trade liberalization undertaken in Chile. This involved the abolition of most non-tariff barriers and a reduction of import tariffs from over 100 percent for some products to a uniform rate of 11 percent across all industries. Using firm-level panel data, Pavcnik finds that the productivity of plants in the import-competing sectors grew 3-10 percent more than in the non-traded goods sector, which suggests that the exposure to international competition forced previously shielded plants to improve their performance. Exiting plants were on average 8 percent less productive than plants that continued to operate.

As noted by Erdem and Tybout (2003), while a large number of studies document that import-competing industries undergo productivity gains following trade reforms (with much of this due primarily to factor use reallocation effects) and that price-cost margins fall as a result of greater competition, it is not straightforward to draw policy conclusions from this literature. This is because it is not clear what drives improved performance- better management incentives; greater returns to innovation; or incentives to shed redundant labor-and what policies are 
critical in affecting these incentives. Domestic distortions (market failures) may be more important than trade policies in determining long-run outcomes.

An increase in competition may also result from FDI inflows. For instance, in a recent World Bank survey of 391 domestic enterprises in the Czech Republic, almost a half of the respondents reported that foreign entry increased the level of competition in their sector. Twenty-nine percent claimed to have lost market share as a result of foreign entry. Similar responses were obtained from a survey of 396 enterprises in Latvia (see Figure 1). The negative correlation between the presence of foreign firms and productivity of domestic enterprises in the same sector found by many studies can be attributed in part to the increased competition resulting from foreign entry. As local firms lose their market share to foreign entrants they are forced to spread their fixed costs over smaller production and thus experience an increase in their average cost (Tybout 2000; Saggi 2002).

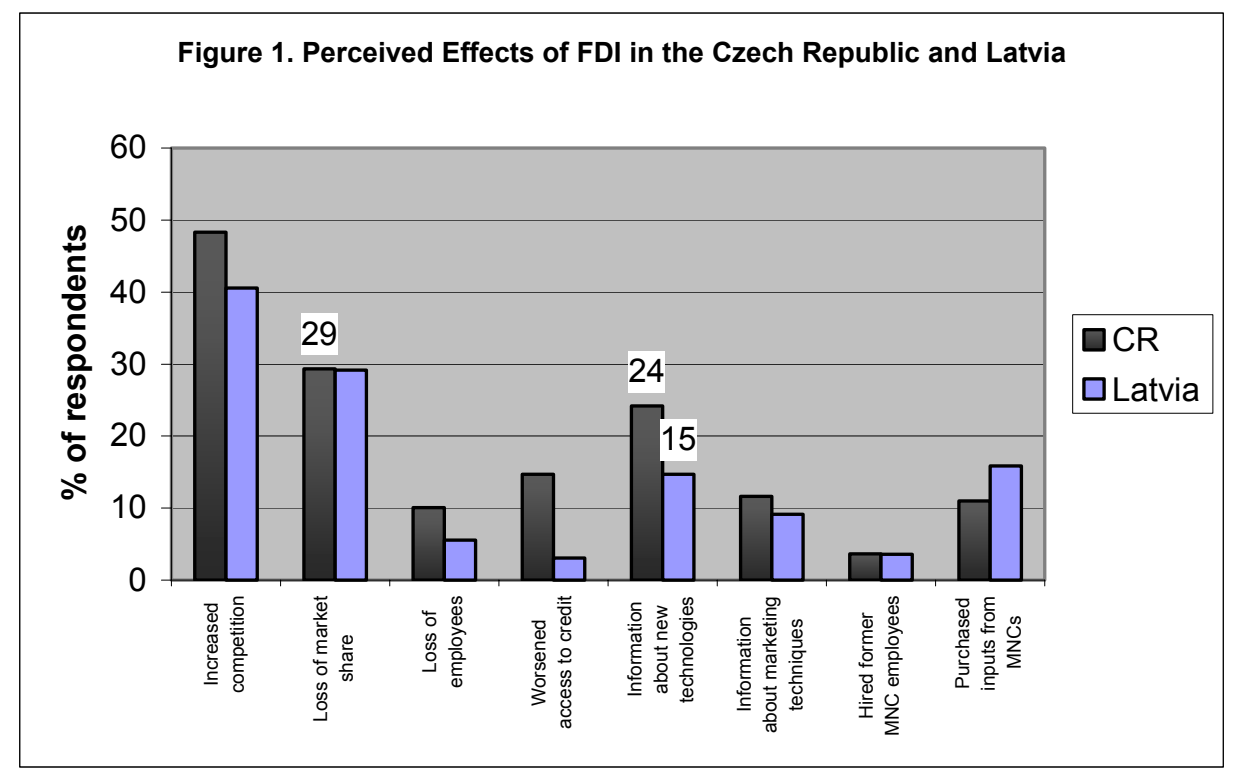

Source: Javorcik and Spatareanu (2004).

Greater competition at the downstream level also affects suppliers of local companies. As multinationals are more likely to rely on imported inputs than domestic producers, an increase in their market share may result in lower demand for locally-produced intermediates and thus may hurt domestic producers in upstream sectors. ${ }^{1}$ An example is the purchase of an equity

\footnotetext{
${ }^{1}$ For a theoretical justification see Rodriguez-Clare (1996), for empirical evidence Javorcik, Saggi and Spatareanu (2004).
} 
stake in the Romanian car producer Dacia by Renault in 1999. The French company promised to continue sourcing inputs from local suppliers, provided they lived up to its expectations. These standards do not appear to have been met, as in 2002 eleven foreign suppliers of the French group were expected to start operating in Romania, thus replacing the local producers from whom Dacia used to source (Ziarul Financiar (Financial Newspaper) April 19, 2001). The situation is also reflected in the results of the Czech enterprise survey mentioned above. Twentyone percent (or 45 of 215) of companies that the respondent had supplied in the past severed the business relationship after being acquired by a foreign investor or setting up a joint venture with a foreign partner. ${ }^{2}$

\section{Technology transfer}

Access to new technologies is a second channel through which globalization affects the performance of indigenous firms. To the extent goods embody technology, such knowledge can be obtained through imports from technologically advanced countries. Empirical support for this is provided by Coe and Helpman (1995) and Coe, Helpman and Hoffmaister (1997), who find a strong positive correlation between a country's productivity and the import-weighted R\&D of its trading partners. This impact is greater the more open the countries are, the more skilled is their labor force, and in the case of developing countries, the more they trade with developed countries (Schiff, Yang and Olarreaga 2002). Investment in R\&D has a greater impact on total factor productivity (TFP) than openness to trade among OECD members, but openness has a greater impact on TFP than R\&D embodied in North-South trade (Schiff and Wang 2002). ${ }^{3}$

These results suggest that open trade policies are critical for developing countries in attracting technology. But openness is not sufficient - there needs to be absorptive capacity and ability to adapt foreign technology, both of which are related to human capital endowments and investment in R\&D intensive industries. In developing countries, technology acquisition often amounts to adapting existing methods to local circumstances (Evenson and Westphal 1995). Gradual adoption of new techniques or new inputs is optimal for risk-averse producers in the face of costly adoption and uncertain returns. Producers need to learn how to apply the new

\footnotetext{
${ }^{2}$ From a labor or employment perspective, the adjustment associated with such shifts is attenuated by the fact that the new entrants will demand local labor.

${ }^{3}$ For North-South trade, Schiff and Wang also find that in low R\&D-intensity industries, openness (R\&D) has a positive (no) impact on TFP, while R\&D has a positive effect on TFP in R\&D-intensive industries, although this effect is still smaller than that of openness.
} 
technology and will often start by applying it to a small part of their output and, if profitable, increase its application gradually over time (Tybout 2000).

FDI is another important mechanism of cross-border technology transfer. The plausibility of this mechanism is supported by theoretical arguments stressing the importance of intangible assets, transfer of technology from headquarters to foreign affiliates (e.g., Markusen 2002) and the fact that most of the world's R\&D effort is undertaken by multinational companies. Existing studies have identified several ways through which technology and knowhow may spill over to indigenous firms in a host country. First, through demonstration effects, i.e., local companies may learn about the existence of new technologies or new products simply by observing multinationals operating in their country. Second, indigenous firms may hire workers previously employed by multinationals, thereby benefiting from the training received by the worker while at the foreign company. Third, foreign entry may generate new or improved intermediate inputs - both goods and (complementary) services.

Results from the surveys mentioned earlier provide support for all three mechanisms of FDI-driven technology transfer. As illustrated in Figure 1, almost a quarter of respondents in the Czech Republic and 15 percent in Latvia reported learning about new technologies from multinationals operating in their countries. Twelve and 9 percent, respectively, benefited from information on new marketing techniques, thus giving support to the demonstration effect. The movement of labor, however, seems to have been less prevalent as only 4 percent of firms reported hiring workers trained by multinationals. Finally, 11 percent of Czech firms and 16 percent of Latvian companies benefited by purchasing inputs from multinationals.

There is a large literature testing for the existence of technology spillovers associated with FDI (Saggi 2002; Gorg and Greenway 2004). Two main findings emerge from the existing studies based on firm-level panel data sets. First, the evidence on intra-industry (or horizontal) productivity spillovers is mixed. For instance, while Haskel, Pereira and Slaughter (2002) find evidence consistent with positive horizontal spillovers from FDI in the United Kingdom, Girma, Greenaway and Wakelin (2002) do not. Many studies focusing on developing countries cast doubt on the existence of spillovers or even produce evidence of negative horizontal spillovers (see Aitken and Harrison, 1999 on Venezuela; Djankov and Hoekman, 2000 on the Czech Republic). 
Damijan et al. (2003) detect the presence of positive intra-industry spillovers in Romania but not in six other transition economies. ${ }^{4}$

A plausible explanation for these mixed conclusions has been proposed by Aitken and Harrison (1999). They postulate that, on the one hand, foreign entry leads to dissipation of knowledge thus potentially facilitating productivity growth in indigenous firms. On the other hand, increased competition from firms with foreign capital may drive up the average costs of domestic producers in the short run resulting in lower observed productivity. Since most studies do not include comprehensive controls for the competition effect, they observe the sum of the two forces and depending on their relative strength find either positive, negative or no effect.

A second finding of the literature is the evidence suggesting the existence of interindustry (or vertical) spillovers from FDI. Multinationals have incentives to prevent knowledge leakage to local competitors operating in the same sector. However, they may have an incentive to transfer knowledge to local suppliers (as they would benefit from the improved performance of intermediate input producers). As a result, the existence of inter- rather than intra-industry effects is more plausible. Moreover, improving the performance of suppliers may often be achieved by transferring general information about modern business practices, such as for instance quality control or inventory management methods, rather than sharing proprietary technologies. Recent evidence consistent with spillovers from multinationals to local suppliers has been found by Blalock and Gertler (2004) in Indonesia and Javorcik (2004) in Lithuania. The magnitude of the effect is economically meaningful: a one-standard-deviation increase in the presence of multinationals in downstream sectors is associated with a 15 percent increase in the productivity of domestic firms in the supplying industries (Javorcik 2004).

\section{Access to new markets}

Trade liberalization is in many cases undertaken in the context of bilateral, regional or multilateral efforts. Indeed, a basic feature of globalization is that the lowering of a country's own trade barriers is accompanied by an improvement in access to foreign markets. Market access in turn creates new opportunities for domestic firms willing to make improvements

\footnotetext{
${ }^{4}$ Javorcik and Spatareanu (2003) show that the presence of spillovers in Romania depends on the extent of foreign ownership in investment projects.
} 
necessary to sell their products abroad or to new customers domestically. ${ }^{5}$ Entering foreign markets is costly as potential exporters are initially disadvantaged relative to indigenous firms as they have to bear transport costs and overcome tariffs and are less familiar with the tastes of local customers and local regulations. Thus only firms with above average productivity are able to compensate for this disadvantage and successfully make sales in foreign countries. The superior performance of exporters, exhibited before they enter foreign markets, is documented by Clerides, Lach and Tybout (1998) and Bernard and Jensen (1999 and 2004). Bernard and Jensen (2004) further demonstrate that trade improves welfare by facilitating the growth of high productivity plants, not by increasing productivity growth at these plants. Thus increased trade results in one-time increases in productivity levels but not the long-term rate of productivity growth.

As Greenaway and Kneller (2004) argue, there exists a pool of firms that do not export but possess observable characteristics similar to exporters. Whether a policy intervention to encourage such firms to become exporters is warranted depends on the underlying reasons why they choose not to enter foreign markets. If the explanation lies in unfavorable unobservable characteristics, such as lower quality of management or product attributes, then policy intervention may be a waste of resources. If, on the other hand, the choice not to export is due to information asymmetries associated with the uncertainty about the costs and the profitability of entry, then an intervention may be beneficial.

Globalization may also create new domestic business opportunities. New foreign entrants as well as domestic firms may be interested in sourcing intermediate inputs locally. A recent World Bank survey of over a hundred multinationals operating in the Czech Republic found that the respondents purchased on average 48.3 percent of their inputs from Czech enterprises, as compared to 33.3 and 12.6 percent from firms in the European Union/Eastern Europe and multinationals located in the Czech Republic, respectively (Javorcik and Spatareanu 2004). Firms operating on global markets will also demand a variety of service inputs - ranging from distribution to maintenance and facilities management—creating additional business opportunities.

\footnotetext{
${ }^{5}$ Baldwin and $\mathrm{Gu}$ (2004) discusses the response of Canadian firms to reductions in tariff barriers between Canada and the rest of the world.
} 
Just like potential exporters need to make improvements to enter foreign markets, the same is true of companies wishing to supply multinational enterprises (MNEs). Many MNEs set high standards for their perspective suppliers by conducting technical audits and requiring quality certifications, such as ISO 9000. The pressure from MNEs is often the driving force behind obtaining quality certifications. For instance, 17 percent of Czech companies surveyed by the World Bank reported getting an ISO certification in order to become MNC suppliers. This group constituted 40 percent of all companies reporting such certification.

Even after starting their business relationship with MNEs, suppliers are under continuous pressure to improve their performance. About a third of suppliers in the Czech Republic reported that MNE customers required the share of defective products to decline over time while 39 percent of suppliers were expected to lower the prices of the products supplied on an annual basis. Similarly, more than a quarter of multinationals surveyed reported that the complexity and/or quality of products bought from Czech suppliers increased during the past two years. In about half of the cases, the improvement was a result of the foreign customer imposing more stringent requirements (Javorcik and Spatareanu 2004).

\section{Government Policies and Firm Adjustment}

Government policies play an important role in the adjustment process. Indeed, a key responsibility of government is not only to ensure that firms confront the "right" incentives to induce investment in activities in which a country has a comparative advantage, but also to assist in facilitating adjustment to technological changes and policy shocks. The latter will generally reflect a mix of economic and social motivations, i.e., it will reflect efforts to overcome market failures and other distortions that may impede adjustment (or make it more costly) as well as the realization of equity (distributional) objectives.

Time consistency of government actions is a key factor in stimulating adjustment. If firms do not believe in the permanency of liberalization or governments are pursuing other policies that make sustaining reforms difficult, firms may choose not to adjust. Instead they are likely to devote resources to lobbying for overturning the reforms. Various instruments can be used to make reforms more credible, including tying them to a multilateral or regional trade agreement or undertaking reforms with the support of international financial institutions. Such instruments may also help implement reforms gradually, thereby reducing period-by-period 
adjustment costs and allowing time for strengthening complementary institutions. Although the overall aggregate costs of gradualism may be higher than a big bang reform in instances where the institutional environment is adequate, gradualism will often have major political economy benefits in terms of feasibility and sustainability. The big challenge of gradualism is, however, credibility.

Credibility depends on many factors, including a stable macroeconomic environment and good fiscal management. Another crucial element is introduction of hard budget constraints, so that firms are forced to close down if they cannot cover their operating costs in the medium term. Thus, bankruptcy procedures are an important part of the equation. If firms expect to be able to access financing for operating losses or capital investment from the state, this will generally distort managerial incentives and resource allocation. Thus soft budget constraints can also directly impede adjustment and the realization of the expected benefits from globalization. Insofar as there are state-owned enterprises, hard budget constraints can be imposed through privatization. Experience suggests that this can have a major impact on managerial incentives to adjust/restructure firms and improve performance. ${ }^{6}$

Equally, if not more important, is strict discipline in the granting of subsidies to firms and industries. Such subsidization may be direct (a budget transfer) or indirect — operating through the tax system (e.g., tax concessions) or through the financial system (e.g., directed credit, interest rate subsidies). If governments provide subsidies or tolerate financial intermediation by the banking system that results in large volumes of nonperforming assets and periodic public bailouts of banks, they will be distorting resource allocation as well as preventing sociallydesirable exit, restructuring and entry of (expansion by) firms into new markets. In extreme cases, countries may end up with banks that are so financially weak they cannot withstand exits and bankruptcies on the needed scale. There is, therefore, an important link between adjustment

\footnotetext{
${ }^{6}$ Claessens and Djankov (2002), for example, document changes in the performance of over 6,000 privatized and state-owned manufacturing enterprises in seven Eastern European countries and find that privatization is associated with significant increases in sales revenues and labor productivity, and, to a lesser extent, with fewer job losses. The positive effect of privatization appears to grow with time. While enterprises privatized for less than 2 years have labor productivity growth similar to that of state-owned enterprises, companies privatized for 3 or more years significantly outperform state-owned enterprises. Similarly, in a recent survey of the literature on the effects of privatization on firm performance Megginson and Netter (2001) conclude than in most settings privatization "works" in that the firms become more efficient, more profitable, financially healthier, and reward investors. While this finding holds in both transition and non-transition economies, there is more variation in transition economies where the identity of the new owners and managers is important in determining post-privatization performance.
} 
and financial sector policies that create incentives for credit to be allocated on the basis of appropriate risk assessment, due diligence and market terms.

Other relevant policies include general interventions that have an economy-wide impact such as a good business environment, infrastructure, education, and rule of law as well as specific actions to address market failures or attain social objectives. When discussing such policies in the remainder of this paper, we will employ the same three-fold typology as above. We begin with competition effects. Trade and investment liberalization are powerful sources of market discipline, but in themselves not sufficient to ensure that markets are contestable. Proactive competition policies broadly defined may be needed to ensure that consumers benefit from lower priced and higher quality goods and services. There may also be a rationale for specific interventions to address externalities. We then move on to technology-related issues. Here also neither technology absorption nor its diffusion is automatic. Absorptive capacity is critical, as are policies to ensure that innovators are able to earn a positive expected return on successful innovation. When it comes to market access polices governments also have a role to play by improving market access of domestic firms through regional or multilateral trade negotiations, welcoming FDI inflows and addressing problems of asymmetric information and enhancing knowledge of new opportunities. Trade agreements can also play a beneficial role in enhancing the credibility of reforms.

\section{Competition: enhancing efficiency, entry and exit}

There are two dimensions to competition-related policies: (i) promoting new activities - the "entry" or expansion side, and (ii) dealing with constraints to factor reallocation - the restructuring and "exit" side of the equation. The importance of both exit and entry "facilitation" is illustrated in recent micro and macro studies. For instance, Criscuolo, Haskel and Martin (2004) find that entry and exit accounted for 25 and 50 percent of UK manufacturing productivity growth over five-year intervals in the 1980s and the 1990s, respectively. Bolaky and Freund (2004) show that increased openness to trade is positively correlated with income in all countries (Figure 2) but is associated with a lower standard of living in economies that heavily regulate new entry or impose high costs on exiting or downsizing (Figure 3$).^{7}$ This prevents resources from moving to the most productive sectors and firms. A large body of micro-

\footnotetext{
${ }^{7}$ The study focuses on regulation of new entry (number of procedures, time and cost involved) and labor market restrictions on new hiring or layoffs.
} 
econometric country studies has found that entry and exit of firms (turnover rates) is a key determinant of positive productivity effects of trade openness (Roberts and Tybout 1997). The policy implication is that trade liberalization needs to be complemented by measures to facilitate/allow reallocation of factors of production, in particular policies to promote domestic competition and labor market flexibility.
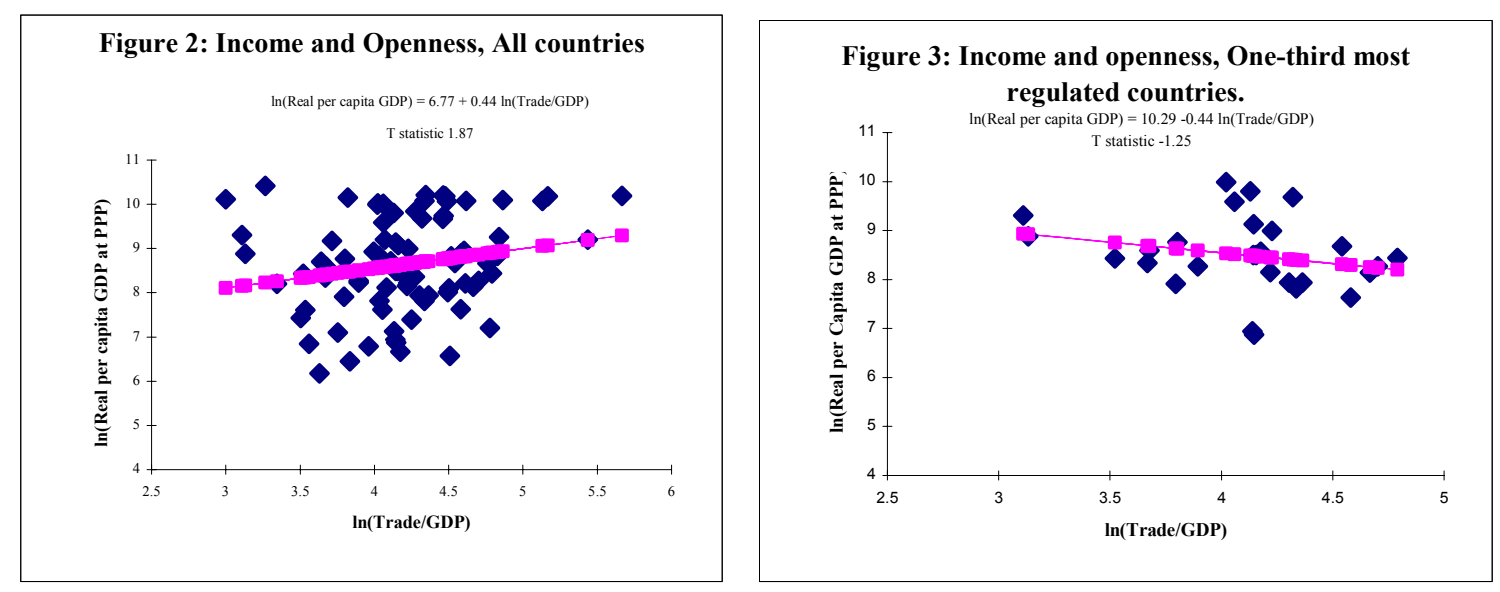

As noted previously, Erdem and Tybout (2003) argue that the empirical literature assessing the impact of trade opening (and FDI) on the performance of domestic (incumbent) firms leaves unclear what drives the observed improvements in management behavior-less Xinefficiency, innovation or factor reallocation within the firm, etc. Thus, there remains a question concerning what types of competition policies are (most) important for welfare. For example, a one-time reduction in import prices as a result of trade liberalization that improves productivity performance through exit of least efficient firms may give way to productivity losses in later periods due to reduced incentives to innovate. This can lower average quality of output available to consumers and thus welfare. In contrast, if the shock is a (sustained) increase in innovation by foreign firms, the welfare impact of greater foreign competition is likely to be positive overall. Although much depends on specific modeling assumptions, complementary domestic policies are clearly important in determining benefits in the longer run.

The issues raised by Erdem and Tybout are related to the literature on alternative "models" of dynamic development of firms. On the one hand, there is the passive learning model of Jovanovic (1982) where managers (owners) passively learn about their ability over time and investment or exit decisions are based on the firm's ex post performance. Ericson and Pakes 
(1995), in contrast, assume owners are fully informed of their abilities and rationally respond to changing circumstances and profitability. The policy implications of these two behavioral setups are different. In the passive framework, exit by low performers and entry of new firms with incomplete information on their "capacity" is the motor of change. This suggests government should promote entry by new firms and remove barriers to exit. However, the Ericson-Pakes framework assumes that managers confronting competitive pressure will seek to improve performance. The policy implication here is that a more proactive stance may make sense for policy: measures to promote innovation $(\mathrm{R} \& D)$ and to assist upgrading of existing firms (Motohashi, 2002). In practice, both models are likely to apply in different sectors (Pakes and Ericson, 1998). ${ }^{8}$ Thus, both policies that facilitate learning about managerial performance and policies that encourage the use of new technology to improve performance are part of the overall policy set.

\section{Restructuring and exit-related policies}

While some adjustment takes place through exit, most firms respond to trade and investment liberalization by adjusting the size and/or composition of their labor force. Thus, flexibility of the labor market as well as the efficiency of the capital market affect the ease of adjustment.

Davidson and Matusz (2000) argue that labor market flexibility plays a role in determining the magnitude of gains from trade liberalization relative to the level of short-run adjustment costs. Using simulations to solve a model in which workers vary according to ability and jobs differ in terms of the skills they require, they demonstrate that economies with sluggish labor markets gain least from trade liberalization. The reason is that the benefits of removal of trade barriers are almost completely offset by large short-run adjustment costs. In contrast, in countries with flexible labor markets the gains from liberalization are always significantly larger than short-run adjustment costs.

Particularly important, although often neglected in practice, are policies toward service sectors. Greater competition in services can be important in facilitating adjustment and exit in declining industries by lowering the cost, quality and variety of services to firms and consumers and creating new opportunities for workers and entrepreneurs. Many of the 'backbone' services such as transport, energy and telecommunications are key inputs into production. Ensuring that

\footnotetext{
${ }^{8}$ Pakes and Ericson (1998) conclude that US firms in the distribution sector appear to be characterized best by the
} 
these markets are contestable is, therefore, an important policy challenge, as it can lower overall adjustment costs. The latter effect can be illustrated with results from the CGE literature on the design and sequencing of reforms. In a study of trade liberalization for Tunisia, Konan and Maskus (2004) find that removing commodity tariffs without services liberalization tends to "over-adjust" the economy toward manufacturing and away from agriculture and services. Freeing up services moves the structure back toward the fully efficient outcome. They show that a "pure" goods-trade liberalization results in a much greater movement of labor and more dramatic changes in the composition of production than a set of reforms that also reduces barriers to entry and lowers operating costs in services sectors. Services liberalization-which also spans entry by MNEs - therefore eases the adjustment costs involved in the liberalization of goods trade as the expansion of economic activity is not restrained by lagging competitiveness of the service sector. ${ }^{9}$ Addressing inefficiencies in services is therefore an important area for policy attention, both to facilitate adjustment (and, indeed, to reduce the aggregate magnitude of adjustment costs) and to create new opportunities for employment (in part through entry of new firms). ${ }^{10}$

What about direct assistance for restructuring of firms or industries? There is a long history of such efforts in many countries. This not only spans subsidies and bailouts but also government involvement in downsizing industry or managing supply through "crisis cartels" and forced consolidation through mergers. While opinions differ, the weight of the evidence suggests that such policies are generally very costly, often prolong the adjustment period and distort competition (Noland and Pack, 2003). The available evidence suggests that policies are better directed at facilitating labor adjustment (through unemployment insurance, retraining programs, and universal health insurance) and addressing specific information asymmetries and related market failures that may impede the entry of firms into new sectors or the creation of new firms. As is often recommended in the case of agriculture, insofar as governments desire to assist in the process of restructuring of industry, a good rule of thumb is to "decouple" assistance to firms

\footnotetext{
passive learning model, while manufacturing firms behavior is more consistent with their framework.

${ }_{9}^{9}$ As illustrated by Griffith, Redding and Simpson (2004) multinationals play an important role in service sectors and are responsible for a substantial amount of $\mathrm{R} \& \mathrm{D}$ effort in these sectors.

${ }^{10}$ See also Hoekman and Konan (2001). Note that the above is not to deny that services are activities where there is often a need for some type of regulation to address problems of asymmetric information or to achieve social objectives. However, such regulation needs to be designed in ways that harness (use) market forces, e.g., by creating incentives for firms to supply disadvantaged groups most efficiently. Space constraints prevent more detailed discussion — see e.g., Mattoo and Carzaniga (2003).
} 
from past production and target subsidies toward workers (and possibly affected communities). Pro-active labor market policies, retraining programs and financing for skills enhancement, as well as general social safety nets are likely to be better approaches toward facilitating adjustment (Richardson, 2003). ${ }^{11}$

That said, it is better to have direct subsidies to firms that confront restructuring challenges than to use trade protection as an instrument to "manage" adjustment. The latter is more costly, less transparent and as a result often captured and difficult to remove. It does nothing to help workers build the right skills and move to firms that provide better long-term opportunities. At least in principle, subsidy programs can be designed to support adjustment efforts through appropriate conditionality, although the practice has not been encouraging.

\section{Entry-related policies}

On the entry side, general government policies that determine the quality of the investment climate are of primary importance. Absent the rule of law, efficient contract enforcement, political stability, human capital and adequate infrastructure, incentives to invest in new opportunities will be reduced. Regulation-related costs of restructuring and exit are also disincentives to invest in the first place.

Specific "entry promotion" policies may be called for to address externalities. Markets do fail and there may be good rationales for governments to provide incentives for agents to undertake activities that would otherwise be undersupplied. An important example that has a direct bearing on the subject at hand is the learning externality analyzed by Hausmann and Rodrik (2002). In that situation the market undersupplies investment by firms in new activities because of appropriability problems; a subsidy or similar incentive can help expand innovation and risk taking. From an adjustment perspective, such encouragement can also help induce a reallocation of investment out of declining sectors. However, the issue is to address the externality, not to prop up uncompetitive firms or industries.

The efficient use of "entry support" policies requires that governments are effective at both identifying cases where externalities potentially justify intervention and at implementing these. In practice, governments may fail at doing so and the policy problem is to assess the

\footnotetext{
${ }^{11}$ Richardson (2003) argues that a more appropriate nomenclature should be "opportunity nets" as the goal of worker directed policies should be to empower them to engage in and benefit more from the process of globalization. That is, the objective should be to help workers benefit from change, not seek to avoid it.
} 
relative sizes of government and market failure. Among the potential problems are that subsidies can serve to support inefficiency; that firms may behave strategically (by under-investing, for example) in order to win subsidies; and that subsidies can result in corruption, bad corporate governance and rent-seeking behavior. The biggest challenge of implementing subsidies is that they are difficult to control. Establishing an effective and credible exit strategy that weeds out successful efforts from unsuccessful ones is difficult and heavily dependent on the capabilities and autonomy of the state (Rodrik, 1993).

One specific policy area that is important is to ensure that the regulatory environment does not inhibit entrepreneurs from exploiting new business opportunities. Entry of new firms should be facilitated by rapid and low cost firm registration procedures. In many developing countries the number of procedures required to establish an enterprise and the costs involved are very high. Djankov et al. (2002) analyze data on the regulation of the entry of start-up firms in 85 countries and find that countries regulating entry more heavily have greater corruption and larger unofficial economies, but not better quality goods (public or private). ${ }^{12}$

Efficient financial intermediation is critical in allowing exploitation of new opportunities. Firm, industry and cross-country studies show that even after correcting for simultaneity bias there is a positive relationship between the level of financial development and economic growth (Beck et al., 2000). This theme is also echoed in the Czech survey mentioned earlier-lack of financing for investments necessary to start supplying MNEs was given by foreign respondents as one of the main reasons why they cannot increase the amount of local sourcing. The inability of local firms to benefit from spillovers in the absence of financing is consistent with the results of Alfaro et al. (2004) who use cross-country data for the period 1975-1995 to demonstrate that FDI alone plays an ambiguous role in contributing to economic growth, but countries with welldeveloped financial markets gain significantly from FDI inflows. Smaller firms in particular are often constrained in their access to bank credit, especially long-term loans. These firms generally rely on own assets and retained earnings for working capital and on trade credit as a source of funds. Fisman and Love (2003) show that in countries with weak financial sectors, industries that rely on trade credit have higher growth rates. Given that start-ups will not have such access, the

\footnotetext{
${ }^{12}$ Among the many negative effects of corruption is that it acts as a tax on foreign investors and has been shown to deter FDI inflows (Wei, 2000; Smarzynska and Wei, 2000). Corruption is also more of a burden on SMEs (Beck et al., 2002).
} 
observed increase in growth is due to existing firms, not an expansion in the number of firms. The latter is of course important in terms of maximizing potential benefits from globalization.

One policy option here is to provide access to long-term credit, which can be done directly by the government or through financial intermediaries by giving them incentives to do so. Numerous countries have pursued such policies, often through credit lines or matching grant schemes, frequently at rates of interest that are below market rates. The experience with such programs varies, but in many cases has been disappointing. A necessary condition for programs of this kind to have the desired effect on expansion of the SME sector and raise the growth rate/profitability of recipient SMEs is that these firms operate in a stable macroeconomic environment and a reasonably good investment climate. Absent these preconditions, projects are much less likely to succeed. It is also not clear that there will be additionality - the beneficiary firms might have obtained financing in any event. A general lesson from experience is that access to credit must be distinguished from access at subsidized rates - to ensure both financial viability and efficient resource allocation, interest rate subsidies should be avoided (Batra and Mahmood 2003).

There is a close parallel between policies aimed at addressing problems of asymmetric information and credit constraints for small firms and increasing 'formalization' in developing countries. The latter is a precondition for sustained growth, as firms in the informal sector by definition will find it impossible to expand beyond a certain size. In many countries with a large informal sector, the regulatory regime may have excessive impacts on smaller firms (including the tax regime), and constitute a major disincentive to become 'formal' ${ }^{13}$ If so, this has implications for benefiting from globalization, as there will be fewer opportunities to create the jobs needed to absorb new entrants into the labor force in addition to those who lose their jobs due to restructuring. The implication is a need to reconsider the costs and benefits of prevailing regulations, which may not be appropriate for small firms. Explicit preferential treatment of SMEs is unlikely to be an appropriate policy, given the presumption in favor of policy neutrality in the absence of externalities — which are often hard to identify. The best approach is to reduce biases against SMEs — which are prevalent in many countries, not just developing economies. This can be done by minimizing compliance costs, removing tax biases against equity finance,

\footnotetext{
${ }^{13}$ For example, Galal (2004) shows how the current regulatory and tax regime in Egypt makes formalization of the representative informal firm prohibitively costly - firms are better off staying informal.
} 
including double taxation of equity (as SMEs are more dependent on equity/less able to obtain debt finance on 'reasonable' terms), and liberal loss carry forward provisions (Chen, Lee and Mintz 2002).

\section{Competition and trade law}

Trade and investment liberalization are powerful sources of market discipline, but in themselves not sufficient to ensure that markets are contestable. Pro-active competition laws and enforcement agencies may be needed to ensure that consumers benefit from lower priced and higher quality goods and services. For example, if there are domestic distortions or monopolies in distribution networks much of the gains from liberalization may accrue to intermediaries, with prices staying higher than they would be if the associated activities were competitive. In a crosscountry empirical analysis of the impact of competition law, controlling for a measure of trade policy, Kee and Hoekman (2003) find that competition law has a positive (marginal) impact on average price-cost markups, illustrating that a pro-active competition policy stance has a role in the policy arsenal of governments. A similar observation holds for trade laws. The easier it is for firms to petition for relief from import competition the lower the incentives for adjustment. Indeed, trade laws can create perverse incentives - both through the prospect of protection, and through the criteria that, if satisfied, increase the probability of obtaining protection. ${ }^{14}$ Space constraints prevent a detailed discussion of trade and competition law. Suffice it to say that the design, wording and interpretation of both can have an important bearing on the overall "adjustment climate" in a country.

\section{Technology and know-how}

Taking advantage of the opportunities created by trade and investment liberalization often requires substantial effort and investment in upgrading the production process. At a general level, neither theory nor experience provides unambiguous guidance regarding the relative social payoff of alternative technology-related policies. Much depends on whether spillovers are international or intra-national, on the capacities to absorb and adapt technologies, and other factors. A 'one size fits all' approach to policy will clearly be inappropriate.

\footnotetext{
${ }^{14}$ Thus, firms will generally have to demonstrate "injury" caused by imports, with injury measured on the basis of trends in profitability, turnover, etc. This may create tension between the market driven reduction in revenue and factor use and the trade law response to these developments, and can even generate an incentive to feign injury.
} 
In a nutshell, the evidence suggests that appropriate policies in this area follow a 'technology ladder' (Hoekman, Maskus and Saggi 2004). While the policy priority in poor countries with weak institutions and limited $\mathrm{R} \& \mathrm{D}$ capacity is to improve the business environment, with liberal trade policies to encourage imports of technology embodied in goods, an important determinant of the ability to absorb and adapt technology is the return to investing in at least simple R\&D capacity. To the extent that prevailing technology policies, restrictions on capital markets, and tax policies lower this return or discourage such investments, reforms can encourage more innovation. Similarly, absorption of technology depends on having an adequate supply of engineering and management skills. In this regard, domestic education and training policies are important. Governments can reduce the 'technological distance' between local and foreign firms by establishing national or regional innovation systems that encourage local R\&D, transfer knowledge from universities and public laboratories to domestic firms, and promote use of telecommunications, e-commerce, biotechnologies, and other cost-saving technologies.

Governments also need to recognize the risk-taking involved in adoption of new technologies. More specifically, suppose domestic firms are considering the costly adoption of some foreign technology but significant uncertainty exists regarding the degree to which the technology can be adopted effectively in the local environment. Under such a scenario, those firms that adopt the technology first will generate positive spillovers for others who can 'watch and learn' from their risky experiments. In the presence of such informational externalities, it may be optimal to subsidize the adoption of foreign technologies (Hoekman et al. 2004). ${ }^{15}$ Provision of public goods such as metrology and standards institutes, as well as appropriate protection of intellectual property rights, especially once a threshold level of development has been reached, are examples of policies that may have high payoffs.

Efforts to stimulate R\&D and greater synergies between basic research and innovation through technology parks, clusters and the like have been an element of policy in many countries. The overall record with such efforts is mixed at best, but they do have the potential to improve productivity. Technology-oriented projects supported by the World Bank and other donors in countries such as India, Mexico and Turkey have been successful in helping firms acquire and use foreign knowledge, although it is always an open question what the 
counterfactual is, as rigorous ex post analysis of performance relative to a control group is often lacking (Batra and Mahmood, 2003).

One policy that has generally not been very successful on the technology front is mandatory technology transfer requirements on foreign-owned companies. Considerable evidence exists that MNEs are keen to transfer technology (Moran, 2001; Saggi, 2002). Policies that facilitate this process, as opposed to those insisting that MNEs transfer know how to local competitors, have a greater likelihood of being successful. If the local economy lacks a welldeveloped network of potential suppliers, MNEs might be hesitant to invest and local suppliers may not develop because of lack of demand. In the presence of such interdependence, growth may be constrained and adjustment costs enhanced by a coordination problem that can partially be resolved by initiating investments from key firms. Such coordination problems may justify temporary incentives as well as policy efforts to improve the investment climate and reduce the costs of absorbing technology. The latter task is complex as it involves building human capital and expanding national innovation systems. Thus, while there may be a case for incentives, it is a conditional one. To be effective, the preconditions relating to the investment climate and absorptive capacity must be satisfied.

\section{Market access-related policies}

An obvious policy priority in terms of opening up access to new markets is international trade negotiations. These have of course played an important role in the external commercial relations of most countries. If firms do not have access to external markets this will constrain their growth. There is a huge literature on the structure and composition of remaining trade and investment barriers. As is often emphasized, for developing countries this agenda revolves around agriculture, labor-intensive manufactures, especially footwear, textiles and clothing as well as services that can be outsourced or require the temporary movement of natural persons. Trade agreements are important not just in lowering foreign trade barriers, they can do much to lower the uncertainty relating to such access, thereby increasing investment into export-oriented production (i.e., foster adjustment). They can also play a valuable role in providing a focal point for domestic reform and enhancing the perceived credibility of such reforms. Whether they do so

\footnotetext{
${ }^{15}$ Note that the issue here cannot be solved through a government buying the knowledge and providing it to all interested parties. The knowledge concerned is not known ex ante and cannot be protected ex post through patents or similar instruments.
} 
depends very much on the objectives of the governments concerned, which can be discerned in part by the contents and coverage of the trade agreement. Some of these are far-reaching and address numerous "behind the border" policy areas - examples are the agreements with countries in line for EU accession, or Mexico-NAFTA. China is an example of a country that used the process of WTO accession as an instrument to commit to extensive liberalization in services industries. However, many trade agreements remain "shallow" in that the focus is limited to trade in goods. Even so, they can play a valuable role in making the associated trade policy reforms credible - due to the associated threat of breakdown of the agreement (retaliation) if the government raises barriers in the future.

Although trade agreements and better access to markets are important for many countries/firms, many developing countries, especially the poorest, already have good access to major markets in that most tariffs and quotas have been removed unilaterally on their exports. The major constraint firms located in these countries face is that they are not cost competitive, often due to internal factors relating to the investment climate. They may also find it difficult to satisfy regulatory requirements or to know about market opportunities. Such issues are likely to be most constraining for smaller firms in these countries. Policy responses may include provision of information, assistance to firms in project development, management or technical skills training. Governments generally have many programs and projects that finance or support a plethora of such technical assistance providers, ranging from purely public, to public-private partnerships to purely private. An example is supplier development programs to facilitate local sourcing on the part of MNEs and thus vertical spillovers from FDI. Such programs have been successfully implemented in Ireland and more recently in the Czech Republic. Participation was offered to promising SMEs that had undergone an evaluation process followed by intense work with outside consultants to make improvement to areas in which they were lacking. Participants were then given opportunities to start new business relationships by meeting with multinationals looking for local suppliers.

The services provided by such entities can be very effective in assisting smaller firms if they are well designed and mobilize the right type of skills and their target audience is aware of the services on offer. In practice all three conditions are frequently not met. As a result, such programs have often been found to have a limited impact at best - in part because the services provided do not generate much value added or because the "wrong" firms get help — those that 
had access to market-based consulting services (in the process creating a potential negative spillover on the private consulting industry). ${ }^{16}$

\section{Concluding Remarks}

The benefits of globalization are conditional on many factors, including the prevalence and impact of domestic distortions that may impede adjustment. In countries with long histories of import substitution or central planning, firms will not have much experience in operating in a global, competitive environment. Trade performance will also be conditioned on what trading partners do. Foreign market access restrictions may lower the prices of exports, raise the prices of imports and have negative effects on the terms of trade, investment incentives and the growth potential of developing countries. Policies therefore have an important role to play in managing the process of globalization.

The literature on policies to encourage adjustment by firms to globalization is both large and diverse. The policies that are most important will vary across countries. One general conclusion that most analysts will agree on is that the business environment or investment climate broadly defined should be the primary focus of policy attention. Without a stable macroeconomy and realistic exchange rate, the absence of anti-export bias, adequate infrastructure, human capital and efficient factor markets, countries will find it very difficult to benefit fully from globalization - and may lose (Helleiner, 2002).

There is certainly scope for specific policies to encourage adjustment. In principle such policies should respond to market failures, which will not be rare in many countries. Priority areas for attention are likely to include finance for smaller firms - access to long term credit — as well as training and the provision of information. In the supply of such services an element of cost sharing will generally be important to ensure there is value added. Although in instances where there are externalities a subsidy is an appropriate instrument, in many cases what is needed is to ensure that policies are neutral toward smaller firms.

The focus of this paper has largely been on the firm. As noted in the introduction, there are other dimensions to managing adjustment. Indeed, a strong case can be made that it is critical that policies focus on helping to distribute the gains from globalization more equally, in part through pro-active policies that help affected workers help themselves. Voters and citizens are

\footnotetext{
${ }^{16}$ See e.g., ADE (2003) for an evaluation of EU assistance programs to Mediterranean countries in this area, as well
} 
much more likely to support globalization when it is explicitly linked with assistance aimed at minimizing labor-market costs. As stressed by Richardson (2003), adjustment policies should be directed at those in society that are less educated and have lower incomes, rather than on an industry or firm specific basis as with traditional trade adjustment assistance in countries like the United States. The gains from globalization are much larger than the overall losses, but there are losers in each society. Reorienting social adjustment-related policies to empower workers so as to strengthen their ability to withstand shocks — of whatever origin — and benefit from the opportunities created by globalization is a necessary complement to the types of policies that have been discussed in this paper.

as Batra and Mahmood (2003). 


\section{References}

ADE, IBM and EPU-NTUA. 2003. "Evaluation of Economic Cooperation between the European Commission and the Mediterranean Countries," Final Report, Vol. 1 (November).

Aitken, Brian J. and Ann E. Harrison. 1999. "Do Domestic Firms Benefit from Direct Foreign Investment? Evidence from Venezuela," American Economic Review. 89(3): 605-618.

Alfaro, Laura, A. Chanda, S.-Ozcan, and S. Sayek. 2004. "FDI and Economic Growth: The Role of Local Financial Markets." Journal of International Economics (forthcoming).

Baldwin, John and Wulong Gu. 2004. "Trade Liberalization: Export-Market Participation, Productivity Growth and Innovation," Oxford Review of Economic Policy, forthcoming.

Batra, Geeta and Syed Mahmood. 2003. "Direct Support to Private Firms: Evidence on Effectiveness," World Bank Policy Research Working Paper 3170.

Beck, Thorsten, R. Levine, and V. Maksimovic. 2000. "Financial Structure and Economic Development: Firm, Industry, and Country Evidence," World Bank Policy Research Working Paper 2423.

Beck, T., A. Demirguc-Kunt and V. Maksimovic. 2002. "Financial and Legal Constraints to Firm Growth: Does Size Matter?," World Bank, mimeo.

Bernard, Andrew B. and J. Bradford Jensen. 1999. "Exceptional exporter performance: cause, effect, or both?" Journal of International Economics. 47:1-25.

Bernard, Andrew and J. Bradford Jensen. 2004. "Exporting and Productivity," Oxford Review of Economic Policy, forthcoming.

Blalock, Garrick and Paul Gertler. 2004. "Welfare Gains from Foreign Direct Investment through Technology Transfer to Local Suppliers," Cornell University, mimeo.

Bolaky, Bineswaree and Caroline Freund. 2004. Trade, Regulations, and Growth. World Bank Policy Research Working Paper 2423.

Bown, Chad P. and Rachel McCulloch. 2004. "US Trade Remedies and the Adjustment Process", mimeo, Brandeis University.

Chen, D., F. Lee and J. Mintz. 2002. “Taxation, Entrepreneurship and SMEs,” DTSI/Doc2002(9). Paris: OECD.

Claessens, Stijn and Simeon Djankov. 2002. "Privatization Benefits in Eastern Europe," Journal of Public Economics. 83(3): 307-324.

Clerides, S. K., Saul Lach and James R. Tybout. 1998. "Is Learning by Exporting Important? Quarterly Journal of Economics 113: 903-948.

Coe, David T., and Elhanan Helpman (1995), "International R\&D Spillovers," European Economic Review 39: 859-87.

Coe, David T., Elhanan Helpman, and Alexander W. Hoffmaister (1997), "North-South R\&D Spillovers," The Economic Journal 107: 13-149.

Criscuolo, Chiara, Jonathan Haskel and Ralf Martin. 2004. "Productivity, Restructuring and Globalisation," Oxford Review of Economic Policy, forthcoming.

Damijan, Joze P., Mark Knell, Boris Majcen and Matija Rojec. 2003. "The role of FDI, R\&D accumulation and trade in transferring technology to transition countries: evidence from firm panel data for eight transition countries," Economic Systems, 27: 189-204.

Davidson, Carl and Steven Matusz. 2000. "Globalisation and Labour Market Adjustment: How Fast and at What Cost?" Oxford Review of Economic Policy, 16(3).

Djankov, Simeon and Bernard Hoekman. 2000. "Foreign Investment and Productivity Growth in Czech Enterprises," World Bank Economic Review, 14(1): 49-64.

Djankov, Simeon, R. La Porta, F. Lopez de Silanes and A. Schleifer. 2002. "The Regulation of Entry," Quarterly Journal of Economics 117:1-37.

Erdem, Erkan and Jim Tybout. 2003. Trade Policy and Industrial Sector Responses in the Developing World: Interpreting the Evidence," Pennsylvania State University, mimeo.

Evenson, R.E. and L. Westphal (1995), “Technological Change and Technology Strategy,” in H. Chenery and T.N. Srinivasan, Eds. Handbook of Development Economics (Amsterdam: North-Holland). 
Fisman, R. and Inessa Love. 2003. "Trade Credit, Financial Intermediary Development and Industry Growth," Journal of Finance 58, 353-374 .

Galal, Ahmed. 2004. "The Economics of Formalization: Potential Winners and Losers from Formalization in Egypt," ECES Working Paper 95 (March), mimeo.

Gorg, Holger and Greenway, D. 2004. "Much Ado about Nothing: Do Domestic Firms Really Benefit from Foreign Direct Investment," The World Bank Research Observer 20.

Girma, S., Greenaway, D. and Wakelin, K. 2001. "Who Benefits from Foreign Direct Investment in the UK?" Scottish Journal of Political Economy 48: 119-133.

Greenaway, David and Richard Kneller. 2004. "Exporting and Productivity in the United Kingdom," Oxford Review of Economic Policy, forthcoming.

Griffith, Rachel, Stephen Redding and Helen Simpson. 2004. "Foreign Ownership and Productivity: New Evidence from the Service Sector and the R\&D Lab," Oxford Review of Economic Policy, forthcoming.

Haskel, Jonathan, Sonia Pereira and Matthew J. Slaughter. 2002. "Does Inward Foreign Direct Investment Boost the Productivity of Domestic Firms?" NBER Working Paper 8724.

Hausmann, R. and D. Rodrik (2002), "Economic Development as Self-Discovery," Harvard University, mimeo.

Helleiner, G.K. (Ed.). 2002. Non-Traditional Export Promotion in Africa. New York: Palgrave.

Hoekman, Bernard and Denise Konan. 2001. "Deep Integration, Nondiscrimination and EuroMediterranean Free Trade," in Jürgen von Hagen and Mika Widgren (eds.), Regionalism in Europe: Geometries and Strategies After 2000, Kluwer Academic Press.

Hoekman, Bernard, Keith Maskus and Kamal Saggi. 2004. "Transfer of Technology to Developing Countries: Unilateral and Multilateral Policy Options,” World Bank Policy Research Working Paper 3332.

Javorcik, Beata Smarzynska. 2004. "Does Foreign Direct Investment Increase the Productivity of Domestic Firms? In Search of Spillovers through Backward Linkages," American Economic Review 94(3): 605-627.

Javorcik, Beata Smarzynska and Mariana Spatareanu. 2003. "To Share or Not To Share: Does Local Participation Matter for FDI Spillovers?” World Bank Policy Research Working Paper 3118.

Javorcik, Beata Smarzynska and Mariana Spatareanu. 2004. "Disentangling FDI Spillover Effects: What Do Firm Perceptions Tell Us?" in M. Blomstrom, E. Graham and T. Moran, eds., The Impact of Foreign Direct Investment on Development: New Measures, New Outcomes, New Policy Approaches, Institute for International Economics, Washington, DC, forthcoming.

Javorcik, Beata Smarzynska, Kamal Saggi and Mariana Spatareanu. 2004. "Does It Matter Where You Come from? Vertical Spillovers from FDI and Investor Nationality," mimeo, World Bank.

Jovanovic, B. (1982), "Selection and the Evolution of the Industry", Econometrica, 50, 649-70.

Kee, Hiau Looi and Bernard Hoekman. 2003. "Imports, Entry, and Competition Law as Market Disciplines," World Bank Policy Working Paper 3031.

Konan, Denis and Keith Maskus, 2004, "Quantifying the Impact of Services Liberalization in a Developing Country", World Bank Policy Research Working Paper 3193.

Leidy, Michael and Bernard Hoekman. 1991. "Spurious Injury as Indirect Rent Seeking: Free Trade under the Prospect of Protection," Economics and Politics, 3, 111-37.

Markusen, J. 2002. Multinational Firms and the Theory of International Trade. Cambridge: MIT Press.

Mattoo, Aaditya and Antonia Carzaniga (eds.). 2003. Moving People to Deliver Services. The World Bank: Washington, DC.

Megginson, W.L. and J.R. Netter. 2001."From State to Market: A Survey of Empirical Studies on Privatization," Journal of Economic Literature, 39(2): 321-389.

Moran, Theodore H. 2001. Parental Supervision: The New Paradigm for Foreign Direct Investment and Development. Washington, DC: Institute for International Economics.

Motohashi, Kazuyuki. 2002. "Use of Plant Level Micro Data for the Evaluation of SME Innovation Policy in Japan,” DTSI/Doc2002(12). Paris: OECD. 
Noland, Marcus and Howard Pack (2003), Industrial Policy in an Era of Globalization: Lessons from Asia. Washington DC: Institute of International Economics.

Pakes, A. and R. Ericson 1998, "Empirical Implications of Alternative Models of Firm Dynamics", Journal of Economic Theory 79, 1-45.

Pavcnik, Nina. 2002. "Trade Liberalization, Exit, and Productivity Improvements: Evidence from Chilean Plants," Review of Economic Studies 69: 245-76.

Richardson, J. David. 2003. Global Forces, American Faces: U.S. Economic Globalization at the Grass Roots: Insights and Conclusions from a Family of Projects," Institute for International Economics, Washington DC, mimeo.

Roberts, Mark and Jim Tybout (eds.). 1997. Industrial Evolution in Developing Countries: Micro Patterns of Turnover, Productivity and Market Structure. New York: Oxford University Press.

Rodriguez-Clare, Andres. 1996. "Multinationals, linkages, and economic development," American Economic Review 85, 852-73.

Rodrik, Dani. 1993. "Taking Trade Policy Seriously: Export Subsidization as a Case Study in Policy Effectiveness," NBER Working Paper 4567.

Saggi, Kamal (2002), "Trade, Foreign Direct Investment, and International Technology Transfer: A Survey," World Bank Research Observer 17, 191-235.

Schiff, M. and Y. Wang (2002), "On the Quantity and Quality of Knowledge: The Impact of Openness and Foreign R\&D on R\&D Spillovers," World Bank, mimeo.

Schiff, Maurice, Yanling Wang and Marcelo Olarreaga (2002), "North-South and South-South TradeRelated Technology Diffusion: An Industry Level Analysis," World Bank, mimeo.

Smarzynska, Beata and Shang-Jin Wei. 2000. "Corruption and Composition of Foreign Direct Investment: Firm Level Evidence from Transition Economies” NBER Working Paper 7969.

Tybout, James (2000), "Manufacturing Firms in Developing Countries: How Well Do They Do and Why?," Journal of Economic Literature 38:11-44.

Wei, Shang-Jin. 2000. "How Taxing Is Corruption on International Investors?" Review of Economics and Statistics. 82 (1): 1-11. 